TI 2014-036/I

Tinbergen Institute Discussion Paper

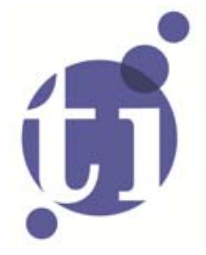

tinbergen
institute

\title{
The Impact of Matching Mission Preferences on Well-being at Work
}

Robin Zoutenbier

Erasmus School of Economics, Erasmus University Rotterdam, and Tinbergen Institute, the Netherlands. 
Tinbergen Institute is the graduate school and research institute in economics of Erasmus University Rotterdam, the University of Amsterdam and VU University Amsterdam.

More TI discussion papers can be downloaded at http://www.tinbergen.nl

Tinbergen Institute has two locations:

Tinbergen Institute Amsterdam

Gustav Mahlerplein 117

1082 MS Amsterdam

The Netherlands

Tel.: +31(0)205251600

Tinbergen Institute Rotterdam

Burg. Oudlaan 50

3062 PA Rotterdam

The Netherlands

Tel.: +31(0)10 4088900

Fax: $+31(0) 104089031$

Duisenberg school of finance is a collaboration of the Dutch financial sector and universities, with the ambition to support innovative research and offer top quality academic education in core areas of finance.

DSF research papers can be downloaded at: http://www.dsf.nl/

Duisenberg school of finance

Gustav Mahlerplein 117

1082 MS Amsterdam

The Netherlands

Tel.: +31(0)20 5258579 


\title{
The Impact of Matching Mission Preferences on Well-being at Work*
}

\author{
Robin Zoutenbier ${ }^{\dagger}$
}

March 17, 2014

\begin{abstract}
A recent literature in economics assumes that workers differ in their mission preferences. These studies predict a premium on the matching of mission preferences between a worker and employer. This paper uses data from the Dutch LISS panel to examine this prediction for government workers. Results show that government workers whose political preferences match those of the political parties in office are more satisfied with the type of work they do as compared to government workers whose political preferences do not match. A match of political preferences has no effect on the job satisfaction of workers outside the government sector.
\end{abstract}

Keywords: job satisfaction, mission motivation, public sector, bureaucrats

JEL: H1, J45, M5

*I gratefully acknowledge comments and suggestions by Josse Delfgaauw, Robert Dur, Jan Tichem, and seminar participants at Erasmus University Rotterdam.

$\dagger$ Department of Economics, Erasmus University Rotterdam, and Tinbergen Institute. E-mail: zoutenbier@ese.eur.nl 


\section{Introduction}

Many organizations strive for objectives other than profits. Such organizations are commonly found in the public sector or in the private non-profit sector. While an entrepreneur in the private non-profit sector chooses her own objectives, the objectives for the public sector, particularly the government sector, are set by politicians. Those employed in the government sector work to meet these objectives. However, these workers may have their private preferences regarding the choice of available objectives to work on. As a result, the preferences of the politicians in office and the private preferences of a government worker are not necessarily aligned.

Recent studies in economics have formalized this idea and have stressed the importance of the alignment of mission preferences between an agent and a principal (Besley and Ghatak 2005, Dur and Zoutenbier forthcoming). A common prediction is that workers enjoy a 'mission' premium in jobs where their private mission preferences match the employer's mission preferences. That is, workers enjoy working on objectives that are in line with their private preferences regarding the available objectives. Closely related is the rich literature on person-organization fit in organizational psychology, that has emphasized the importance of congruence of values between a worker and an organization for attraction, retention, and performance (Kristof 1996). The theory of person-organization fit has also been studied in a public sector context. Studies in public administration have shown that public sector workers who find it important to be able to help others, report higher job satisfaction in jobs that offer the opportunity to help others (Bright 2008, Steijn 2008, Taylor 2008, and Wright and Pandey 2008).

This paper uses survey data on Dutch workers to test whether there exists a premium on the matching of mission preferences within the government sector. More specifically, I examine whether government workers are more satisfied with their job if their private mission preferences are better aligned with the mission of the government in office. While previous studies have exclusively used cross-sectional data on 'mission alignment' or 'value congruence', this paper exploits panel data from the Longitudinal Internet Studies for the Social sciences (LISS). The sample covers a period from 2008 up to 2011. The detailed questions on respondents' occupation details, political 
preferences, and individual characteristics offer a unique opportunity to examine the effects of the alignment of mission preferences in the government sector. A worker's mission alignment is proxied by comparing a worker's reported vote in parliamentary elections to the outcome of the formation of a coalition government after the election. I classify a worker's preferences as a match to those of the government, if a worker voted for one of the political parties that is in office after the election. A worker's preferences do not match when a worker voted for one of the parties that is not in office after the elections. Next, self-reported job satisfaction is used to measure a worker's well-being in a job. Job satisfaction is measured by the question: "How satisfied are you with the type of work that you do?" This facet of job satisfaction relates most closely to a worker's satisfaction with work itself (which is of prime interest given the subject of study). Finally, I restrict the focus of the analysis to workers who are employed in the government sector rather than all workers in the public sector. The measure of mission alignment used in this paper seems more important for those workers under the most direct control of the politicians in office. In contrast, the measures used in the previously mentioned studies on person-organization fit apply more widely to all jobs in the public sector.

The results of the empirical analysis are in line with the hypothesis. I find clear evidence of a premium in job satisfaction on the matching of mission preferences in the government sector. Government workers who match on political preferences to the political parties in office report significantly higher job satisfaction as compared to workers whose preferences do not match. The estimated difference in reported job satisfaction is .391 points. The size of this effect is comparable to the effect of half an hour reduction in commuting time and is even larger than the effect of having to work overtime on a regular basis. The effect of a match of political preferences is insignificant for workers employed outside the government sector. Additionally, the results are robust to including both individual and time fixed effects and controlling for a rich set of individual characteristics (age, education level, and health) and job characteristics (working hours, income, overtime, irregular hours, supervising task, commuting time, tenure, and job type).

My results nicely complement the existing empirical studies on personorganization fit. Moreover, studies on job satisfaction in economics have found that public sector workers report higher job satisfaction as compared to private sector workers (see for instance Clark and Senik 2006). I find a similar result. Government workers report, on average, higher job satisfaction as 
compared to workers employed outside the government sector. Interestingly, this difference is partly explained by the matching of political preferences. Only those workers who match on political preferences to the political parties in office enjoy significantly higher job satisfaction in the government sector. The estimated effect on job satisfaction is positive but insignificant for a non-matching worker at .420 points, but is highly significant and doubles in size for a matching worker (with an estimated effect of .819 points).

Previous studies have shown that mission motivation is especially important for higher educated workers (Lewis and Frank 2002, Dur and Zoutenbier forthcoming). In contrast to these studies I find that matching political preferences are particularly important for government workers with intermediate levels of education. The effect of a match of political preferences is almost twice as large for government workers in the intermediate education categories as compared to the full sample of workers. The results for workers in the lowest or highest education categories are slightly weaker as compared to the full sample.

In a parliamentary system, such as the Dutch system, a government in office usually consists of a coalition of political parties rather than a single political party. This implies that even if a worker's preferred political party (as measured by their vote) makes it into government, it is still possible that this party will form a coalition with political parties that are conflicting with a worker's preferences. Using information on a worker's reported stance towards individual political parties shows that it is not only important if the party a worker voted for takes up office, but also how a worker rates all of the political parties in a coalition. Government workers with a more positive attitude towards all coalition parties report significantly higher job satisfaction as compared to workers with a more negative stance. A similar effect is found when assessing the relative difference in a worker's stance towards the coalition parties as compared to a worker's stance towards the opposition parties. Government workers who rate the coalition parties more favorably than the opposition parties report significantly higher job satisfaction. The reverse is found for government workers who rate the coalition parties more negatively than the opposition parties.

I continue as follows. The next section briefly discusses the relevant literature on job satisfaction. Section 3 describes the data used in testing and explains the empirical strategy. The results of the empirical analysis are reported and discussed in section 4 . Section 5 concludes. 


\section{Related literature}

There is a growing literature in economics on people's subjective well-being (see Frey and Stutzer 2002 for an extensive discussion on well-being measures and applications). A main field of interest in this literature is well-being at work or job satisfaction. Following the seminal paper by Freeman (1978), a number of studies have examined the role of job satisfaction as a predictor of labour market outcomes. These studies have documented strong associations between job satisfaction and behavior in the workplace, such as job quits (Akerlof et al. 1988, Clark et al. 1998, and Shields and Ward 2001), absence rates (Clegg 1983), and counterproductive activities in the workplace (Mangione and Quinn 1975). A second strand of job satisfaction literature has examined the determinants of a worker's job satisfaction. Job satisfaction has been explained by a variety of different individual and job characteristics such as: a worker's age, gender, education, wage and tenure (Hamermesh 1977, Borjas 1979, Clark and Oswald 1996, Clark 1997).

More recently, a number of studies have examined differences in subjective well-being between public sector and private sector employment (Blanchflower and Oswald 1999, Cabral Viera 2005, Diaz-Serrano and Cabral Viera 2005, Demoussis and Giannakopoulos 2007, and Ghinetti 2007). The evidence on a public-private sector differential in subjective well-being is mixed across countries. However, for most countries a public sector premium is found for a variety of different facets of job satisfaction. It is often argued that this differential in job satisfaction is a result of intrinsic motivation or high job security in the public sector (see e.g. Luechinger et al. 2006).

Few studies have tried to empirically explain differences in subjective well-being between public sector and private sector workers. A notable exception is a study by Luechinger et al. (2008). They find that differences between countries in public-private sector life satisfaction differentials ${ }^{1}$ are partly explained by cross-country differences in regulatory policies and institutional constraints for the public sector. Other studies have attributed the difference in subjective well-being between public sector and private sector workers to sorting. Heywood et al. (2002) use data on British workers and find no evidence of a public sector premium after controlling for unobserved heterogeneity between individuals. This indicates that the positive premium

\footnotetext{
${ }^{1}$ A worker's job satisfaction is often considered as part of a worker's general subjective well-being or life satisfaction (Clark and Oswald 1996 and Van Praag et al. 2003).
} 
found in some studies is mainly the result of sorting. People who tend to report greater subjective well-being are more likely to work in the public sector (this is confirmed in a study by Luechinger et al. 2010). These results generalize to a number of facets of job satisfaction such as satisfaction with work itself, pay, and the relation with the boss. Lastly, Clark and Senik (2006) do find a significant premium for public sector workers in Britain and France after controlling for unobserved heterogeneity between individuals. However, they do not condition on wages indicating that these rents are (partly) a result of wage rents in the public sector (although for the French sample this is less likely). Again, these results generalize to a number of facets of job satisfaction including satisfaction with work itself.

Closely related to this paper are studies in public administration that examine how person-organization fit relates to job satisfaction using data on public sector workers. A common finding in this literature is that public sector workers who rate it important to help others, and in addition, find that their job offers the opportunity to help others report higher job satisfaction as compared to public sector workers who do not find that their job offers the opportunity to help others (Bright 2008, Steijn 2008, Taylor 2008, and Wright and Pandey 2008). Additionally, Leisink and Steijn (2009) show that these workers also report a higher willingness to exert effort. ${ }^{2}$ This paper differs from the studies on person-organization fit in two ways. First, this paper uses data on workers from all sectors of the economy, which allows to compare the found results on government workers to non-government workers. Second, studies on person-organization fit have used only cross sectional variation in 'mission matching' to determine an effect on job satisfaction whereas this paper exploits variation within the individual over time.

\section{Data and empirical strategy}

The data used in this paper come from the Longitudinal Internet Studies for the Social sciences (LISS), conducted by CentERdata. ${ }^{3}$ The LISS panel is

\footnotetext{
${ }^{2}$ Closely related to this study are a number of (field and lab) experiments in economics on mission motivation (Tonin and Vlassopoulos 2010, 2012, Fehrler and Kosfeld 2012, Gerhards 2012, and Carpenter and Gong 2013). These studies invariably find that participants with aligned mission preferences exert more effort in a chosen or real effort experiment as compared to participants with conflicting mission preferences.

${ }^{3}$ For more information on the LISS panel study see www.lissdata.nl.
} 
a representative panel for the Dutch population aged 16 and older, covering roughly 5000 households. Panel participants were selected through random sampling from the community registers of Statistics Netherlands. The LISS panel is an unbalanced panel, the first wave dates back to 2008 and the most recent wave has been completed in 2012. Panel members are contacted on a monthly basis to answer questions from a specific survey module. The panel includes modules on work and schooling, health, political values, and a survey on a number of demographic characteristics. Each module is administered only once a year (with exception of the demographic survey) resulting in a yearly survey data structure.

The key variables of interest from this data set are a worker's political preferences, job satisfaction, and industry of employment. Workers' political preferences, as measured by the question: "For which party did you vote in the parliamentary elections of [22 November 2006/9 June 2010]?", are used to construct a variable indicating whether a worker matches on mission preferences to the government in office. A worker is considered as a match when the political party that the worker has voted for in the foregoing elections has taken up office in that specific time period. ${ }^{4}$ A worker is classified as not matching when a worker indicated to have voted for a political party that has not become part of the government in office. ${ }^{5}$

Furthermore, the survey includes a number of statements on facets of job satisfaction (such as wage, hours, career, atmosphere at work, and type of work). Respondents were asked to score themselves on a eleven-point scale ranging from "Not at all satisfied" to "Fully satisfied". I use the facet of job satisfaction that relates most to satisfaction with work itself, measured by

\footnotetext{
${ }^{4}$ The Netherlands has a parliamentary political system with proportional representation in the house of representatives. In a parliamentary system, political parties that have a (coalition) majority in the house of representatives are able to take office as a government. Such a majority is sufficient to implement policies. Political parties in office after the elections of November 2006 are CDA (Christian Democrat party), PvdA (Labour party), and CU (Christian Union party). Political parties in office after the elections of June 2010 are VVD (Liberal party) and CDA (Christian Democrat party) with support of the PVV (Freedom party) in parliament.

${ }^{5} \mathrm{~A}$ possible bias would occur if people are dishonest about revealing their vote in the foregoing parliamentary elections. While it is not possible to observe whether a respondent reports honestly, respondents were given the opportunity to indicate that they "do not know" what they had voted or indicate that they "prefer not to say" on which party they voted. The number of observations in these categories is very low, namely between 1 and 5 percent each year.
} 
the question: "How satisfied are you with the type of work that you do?"6

Finally, respondents indicated their sector of employment by answering the question: "In what sector do you work?" Respondents who answered: "Government Services, Public Administration and Mandatory Social Insurances" are labelled as a government worker, those who answered differently are labeled as a non-government worker. ${ }^{7}$ The focus of the analysis is on government workers rather than all workers in the public sector. Government workers are under most direct control of the government and, therefore, should benefit most when their preferred political party is in office.

The sample is restricted to observations from the 2008 to 2011 wave. The 2012 wave is excluded from the analysis because at the time of data collection there was no active government in office, making it difficult to define the matching variable. This restriction leads to a sample of 1714 unique observations for whom there is data on employment details, political preferences, and a number of demographic variables.

Two methodical issues arise when trying to estimate the effect of a worker's political preferences on a worker's job satisfaction using longitudinal data. First, a test proposed by Wooldridge (2002, pp. 290-291 $)^{8}$ shows that the fixed effects model is preferred to the random effects model $(p<.01)$, to account for unobserved heterogeneity between individuals. The second issue relates to the ordinal nature of the measure of job satisfaction. Several solutions have been put forth to account for endogeneity of individual effects in models estimating ordinal relationships. ${ }^{9}$ A drawback of these ordinal fixed effects methods is that the estimated coefficient size is very difficult to in-

\footnotetext{
${ }^{6}$ The results of the analysis are similar but slightly weaker when measuring job satisfaction by the more general question: "How satisfied are you, all in all, with your current work?". No significant effect is found on a worker's satisfaction with wages, hours worked, career, or atmosphere at work.

${ }^{7}$ Other answer categories include: Agriculture, Forestry, Fishery and Hunting, Mining, Industrial Production, Utilities, Construction, Retail trade, Catering, Transport, Storage and Communication, Financial, Business Services, Education, Healthcare and Welfare, Environmental Services, Culture, Recreation and other services, and Other.

${ }^{8}$ In contrast to the Hausman test, the test proposed by Wooldridge (2002) allows for clustering of errors at the individual level.

${ }^{9}$ See for instance Winkelmann and Winkelmann (1998) who suggest to choose a cutoff point and estimate a fixed effect binary logit, Ferrer-i-Carbonell and Frijters (2004) who allow cut-off points to differ over individuals, and Das and Van Soest (1999) or Baetschmann et al. (2011) who combine estimates for each possible cut-off point made possible by the data.
} 
terpret due to the inability to estimate ordinal category thresholds. Given that the ordinal fixed effects methods offer no benefits in interpretation over the linear fixed effects specification, I use a cardinal scale of job satisfaction in the estimation. Geishecker and Riedl (2012) show that the assumption of cardinality still allows to interpret the results in ratio's of parameter estimates. A feel for the size of an effect can be obtained by comparisons with other estimates from the same regression.

The following specification is used in estimation:

$$
J S_{i t}=\delta G_{i t}+\theta M_{i t}+\psi\left(G_{i t} \times M_{i t}\right)+x_{i t}^{\prime} \beta+\alpha_{i}+\tau_{t}+\varepsilon_{i t} .
$$

The dependent variable, denoted by $J S_{i t}$, is the job satisfaction of worker $i$ in time period $t$. The main variables of interest are a dichotomous variable $G_{i t}$ indicating whether a worker is employed in the government sector or not, a dichotomous variable $M_{i t}$ indicating whether a worker matches on political preferences to the government in office or not, and an interaction between the government variable and the matching variable. Additionally, I include time varying control variables $x_{i t}$, individual fixed effects $\alpha_{i}$, and time fixed effects $\tau_{t}$. Following the hypothesis, I would expect that a match of political preferences has no effect when a worker is not employed in the government sector, so $\theta=0$. Whereas for workers employed in the government sector a match of political preferences should have a positive effect $\theta+\psi>0$, because such a worker can work on policy measures that are in line with a worker's private preferences regarding such a policy.

Table 1 shows the descriptive statistics of the sample including a short description of each variable used in estimation. Average job satisfaction in the sample is around 7.7 on a scale to 10 . Roughly 13 percent of all workers are employed in the government sector, corresponding to 131 to 189 observations each year. The fraction of workers that voted for a political party that has become part of the government in office varies between 44 and 47 percent each year. Figure 1 shows that the difference in job satisfaction between government workers and non-government workers is relatively small over the observation period. Looking closer at the job satisfaction of government workers over time in Figure 2, I find that job satisfaction of matching government workers is slightly higher as compared to non-matching government workers in each observation year (although only significant in 2008 and 2010). Additionally, Table 2 shows the distribution of reported votes over political parties. Almost 75 percent of all workers voted for one of the four 
larger political parties. The remaining 25 percent of workers indicated to have voted for one of the many smaller parties. The differences in voting between government and non-government workers are small. There are a few exceptions, for instance, government workers are more likely to vote Labor party or Christian Union and less likely to vote Christian Democrats party, Socialist party, or Green party. ${ }^{10}$

\section{Results}

Table 3 shows the results of the linear fixed effects estimation using the full sample of workers. The size of the coefficient estimates should be interpreted with some caution due to the ordinal nature of the response variable. ${ }^{11}$ The reported standard errors are clustered at the individual level to account for correlation of errors over time within the individual. The first estimation includes only a dummy indicating whether a worker is employed in the government sector and a dummy indicating whether a worker matches on political preferences to the political parties in office. In line with previous literature, I find that workers in the government sector report higher levels of job satisfaction as compared to workers in other sectors. The difference in reported job satisfaction is .578 and significant. The effect of a match of political preferences for workers in all sectors in the economy is insignificant and very close to zero (with a point estimate of .001).

The second column of Table 3 additionally includes an interaction between a worker's sector of employment and the variable match. Results show that government workers with private political preferences that match those of the political parties in office are significantly more satisfied with their

\footnotetext{
${ }^{10} \mathrm{~A}$ number of studies have examined the political preferences of government workers. These studies find that government workers, as compared to the general population, are more likely to be left-wing orientated (Rattso and Sorensen 2013), although this does not always translate into a higher likelihood to vote for left-wing or socialist parties (Knutsen 2001, 2005, and Jensen et al. 2009).

${ }^{11}$ It is important to note that all of the reported main results are robust to performing the analysis using an ordinal fixed effects method (see table A.1 in Appendix A). This result is in line with Ferrer-i-Carbonell and Frijters 2004 who find evidence that the bias of the linear fixed effects estimator is generally small when using ordinal data. The ordinal fixed effects estimator used in comparison is the 'blow-up and cluster' estimator (see Baetschmann et al. 2011 for an extensive discussion). Geishecker and Riedl (2012) show that this method performs as well as or better than the other available ordered fixed effects methods.
} 
job as compared to government workers with non-matching political preferences. The estimated interaction coefficient of government employment with match is positive and highly significant. This interaction effect is interpreted by looking at marginal effects. A match of political preferences for workers within the government sector is associated with significantly higher job satisfaction; the estimated effect $(\theta+\psi)$ is .349 with a p-value of .025 . In contrast, a match of political preferences for workers outside the government sector seems to be of little importance for a worker's reported job satisfaction. The conditional coefficient for match is slightly negative at -.050 but highly insignificant. These results clearly indicate a premium in job satisfaction on the matching of political preferences in the government sector. ${ }^{12}$

Moreover, a number of recent studies in economics have shown that public sector workers report significantly higher levels of job satisfaction as compared to private sector workers (although this result is not robust to controlling for individual fixed effects and income, see Heywood et al. 2002). I find no significant effect of government employment for workers who do not match on political preferences to the political parties in office. The conditional coefficient is positive at .420 but insignificant. In contrast, becoming a government worker seems to have a particularly positive effect when a worker has matching political preferences. The marginal effect has doubled in size (.819) and is highly significant $(p=.010)$.

Next, column 3 includes a number of time varying demographic and job characteristics as control variables. The effect of a match of political preferences for government workers is robust in both sign and significance; the effect increases slightly from .349 to .391 and remains highly significant. ${ }^{13}$ Likewise, the effect of a match of political preferences for workers outside the government sector reduces slightly from -.050 to -.042 and remains insignificant. Several of the demographic control variables turn out to have a

\footnotetext{
${ }^{12}$ Additionally one may wonder whether all workers in the public sector enjoy higher job satisfaction when their political preferences match to the political parties in office. Robustness analyses show that public sector workers experience a small but highly insignificant mission premium. This indicates that the findings of this paper are indeed specific to workers employed in the government sector rather than workers from the public sector as a whole.

${ }^{13} \mathrm{~A}$ feel for the size of the estimated effects is found by comparing the estimates for the key variables to the estimates of the control variables. For instance, the effect of a match of political preferences for government workers $(.391)$ is equivalent to a half an hour reduction in daily (one way) commuting time and is even larger than the effect of having to work overtime on a regular basis.
} 
significant impact on job satisfaction. Older workers are less satisfied with their job as compared to younger workers, although this effect is decreasing as workers grow older. The results do not show a clear effect of education. The lowest and highest educated workers are more or less equally satisfied with their job but the intermediate educated workers are much less satisfied (although marginally insignificant $p=.102$ ). A workers subjective health score seems to matter only when the assessed health is very poor. Workers with at least moderate levels of health enjoy similar levels of job satisfaction. There are also some remarkable effects of job characteristics on job satisfaction. For instance, workers who are expected to work overtime and workers who need to travel long to get to work are significantly less satisfied with their job. On the other hand, a worker's reported job satisfaction increases in the gross monthly income of a worker. Finally, the time fixed effects, which control for unobserved differences between years, are jointly significant $(p<.01)$.

Previous research has shown that mission motivation is more important for higher educated workers (Lewis and Frank 2002, Dur and Zoutenbier forthcoming). To assess differences between education levels I estimate equation (1) including all two-way and three-way interactions between the variables government, match and three education dummies (low education, intermediate education, and high education). ${ }^{14}$ Table 4 reports the marginal effects for each education category. In contrast to the previous literature I find that not the highly educated government workers but the intermediate educated government workers are affected most by matching mission preferences. The effect of a match of political preferences for intermediate educated government workers is .697 and highly significant. The marginal effect for low or high educated government workers is smaller and almost of equal size to the full sample, but insignificant. In line with the main results, a match of political preferences has no effect on job satisfaction for any education category of workers employed outside the government sector. The differences between education levels in the effect of matching political preferences for government workers is mainly explained by differences in the marginal effect of government employment for non-matching workers. Table 4 additionally

\footnotetext{
${ }^{14}$ The low education category contains all workers who have completed only primary school or intermediate secondary education, the intermediate education category includes all workers who have completed higher secondary or intermediate vocational education, and the high education category includes all workers who have completed higher vocational or university education.
} 
shows the marginal effect of government employment for matching and nonmatching workers. Becoming a government worker has the same effect at any education level for workers with matching political preferences. The marginal effect ranges from .703 for higher educated government workers to .773 for lower educated government workers. There are, however, substantial differences across education levels in the effect of becoming a government worker for workers whose political preferences do not match. The marginal effect for lower educated workers (.316) and, in particular, higher educated workers (.488) is much larger as compared to the marginal effect for intermediate educated workers $(-.044)$. As a result, the differences between matching and non-matching workers are largest in the intermediate education category.

In the Netherlands the government in office usually consists of multiple political parties, also referred to as a coalition government. This implies that even if a worker's preferred political party (as measured by their vote) makes it into government, it is still possible that this party will form a coalition with political parties that are conflicting with a worker's preferences. Table 5 shows the reported stance towards individual political parties for both government and non-government workers. ${ }^{15}$ There are relatively small differences in reported stance between government and non-government workers. The most remarkable differences are found for the parties at the far left and far right. Government workers are significantly less positive about the Socialist party and Freedom party as compared to non-government workers.

Table 6 shows the results of the analysis using the information on a worker's stance towards individual political parties. Column 1 shows the effect of a worker's stance towards the largest coalition party on reported job satisfaction. Government workers who report a more positive stance towards the largest party in a coalition enjoy higher levels of job satisfaction as compared to workers with a less positive stance. The standardized marginal effect equals .122 and is marginally significant. Additionally, the estimation in column 2 shows that it is far more important whether a worker's stance towards all political parties in a coalition is positive. A worker's stance towards the entire coalition is measured by a worker's average rating of all individual coalition parties. Government workers with a more positive stance towards all coalition parties report significantly higher levels of job satisfaction as compared to those with a more negative stance. The marginal effect of a

\footnotetext{
${ }^{15} \mathrm{~A}$ worker's opinion of a political party is measured on a ten-point scale using the question: "What do you think of [party name]?".
} 
standard deviation increase for government workers equals .162. In line with the main results, a worker's stance towards coalition parties is unimportant for job satisfaction of workers in other sectors of the economy. These results are robust to weighting the political parties by their number of seats in parliament. The standardized marginal effect reduces slightly from .162 to .154 but remains highly significant.

Next, column 4 of Table 6 reports the results using information on the relative difference between a worker's reported stance towards coalition parties and opposition parties. The results are very much in line with the previous columns. Workers in the government sector who have a more positive stance towards the coalition parties as compared to the opposition parties enjoy significantly higher levels of job satisfaction than workers with a more positive stance towards the opposition parties as compared to the coalition parties. The marginal effect of a standard deviation increase for government workers equals .131 and is highly significant. Column 5 shows that these results are robust to weighting political parties by their number of seats in parliament. The standardized marginal effect increases slightly from .131 to .135. These results indicate that it is not only important whether a worker's first preference (as measured by their vote) matches to the political parties in office, but also what other parties have joined the coalition government after the election. A natural explanation is that, in the Netherlands, government policy is a result of intensive negotiations by coalition parties on the policy matters at hand. Therefore, political parties in office often have to compromise when making policy plans.

\section{Concluding remarks}

This paper has studied how matching mission preferences affect job satisfaction of government workers using a sample of Dutch workers. Results show that government workers whose mission preferences (as measured by their vote in parliamentary elections) match those of the political parties in office are more satisfied with their job as compared to government workers whose preferences do not match. No similar effect is found for workers employed outside the government sector. Moreover, my results show that public sector workers report higher job satisfaction as compared to private sector workers. This difference is partly explained by matching mission preferences. Only those workers whose mission preferences match those of the political parties 
in office are significantly more satisfied when employed in the government sector. The results are particularly strong for intermediate educated workers. Furthermore, results show that it is not only important if a worker's preferred party takes up office (as measured by their vote), but also how a worker rates all of the other parties that have taken up office.

An interesting addition to this study would be to examine how matching mission preferences relate to sorting. Theory predicts that workers sort to organizations they share a mission with (Besley and Ghatak 2005, Dur and Zoutenbier forthcoming). This leads to two interesting implications. First, employee turnover should be higher following election years with a change in government as compared to years without a change in government. As a change in government (and therefore mission) would create an exogenous shock to workers' mission motivation. Second, one would expect an inflow of workers whose mission preferences match those of the government, while the outflow of workers should consist largely of workers whose mission preferences conflict with the mission of the government. Unfortunately it is not possible to shed light on these issues using the LISS data. 


\section{References}

[1] Akerlof, George A., Andrew K. Rose, and Janet L. Yellen (1988), Job Switching and Job Satisfaction in the US Labor Market, Brookings Papers on Economic Activity, 2: 495-594.

[2] Baetschmann, Gregori, Kevin E. Staub, and Rainer Winkelmann (2011), Consistent Estimation of the Fixed Effects Ordered Logit Model, IZA Discussion Paper No. 5443.

[3] Besley, Timothy and Maitreesh Ghatak (2005), Competition and Incentives with Motivated Agents, American Economic Review, 95(3): 616636.

[4] Blanchflower, David G. and Andrew J. Oswald (1999), Well-being, Insecurity and the Decline of American Job Satisfaction, Mimeo, Dartmouth College.

[5] Borjas, George J. (1979), Job Satisfaction, Wages, and Unions, The Journal of Human Resources, 14(1): 21-40.

[6] Bright, Leonard (2008), Does Public Service Motivation Really Make a Difference on the Job Satisfaction and Turnover Intentions of Public Employees?, American Review of Public Administration, 38(2): 149-166.

[7] Cabral Viera, José A. (2005), Skill Mismatches and Job Satisfaction, Economics Letters, 89(1): 39-47.

[8] Carpenter, Jeffrey and Erick Gong (2013), Motivating Agents: How Much Does the Mission Matter?, IZA Discussion Paper No. 7602.

[9] Clark, Andrew E. (1997), Job Satisfaction and Gender: Why are Women so Happy at Work?, Labor Economics, 4(4): 341-372.

[10] Clark, Andrew E., Yannis Georgellis, and Peter Sanfey (1998), Job Satisfaction, Wage Changes and Quits: Evidence From Germany, Research in Labor Economics, 17: 95-121.

[11] Clark, Andrew E. and Andrew J. Oswald (1996), Satisfaction and Comparison Income, Journal of Public Economics, 61: 359-381. 
[12] Clark, Andrew E. and Claudia Senik (2006), The (Unexpected) Structure of "Rents" in the French and British Labour Markets, Journal of Socio-Economics, 35(2): 180-196.

[13] Clegg, Chris W. (1983), Psychology of Employee Lateness, Absence, and Turnover: A Methodological Critique and an Empirical Study, Journal of Applied Psychology, 68(1): 88-101.

[14] Das, Marcel and Arthur van Soest (1999), A Panel Data Model for Subjective Information on Household Income Growth, Journal of Economic Behavior and Organization, 40(4): 409-426.

[15] Demoussis, Michael and Nicholas Giannakopoulos (2007), Exploring Job Satisfaction in Private and Public Employment: Empirical Evidence From Greece, Labour, 21(2): 333-359.

[16] Diaz-Serrano, Luis, and José A. Cabral Vieira (2005), Low Pay, Higher Pay and Job Satisfaction Within the European Union: Empirical Evidence from Fourteen Countries, Mimeo, National University of Ireland.

[17] Dur, Robert and Robin Zoutenbier, forthcoming, Working for a Good Cause, Public Administration Review.

[18] Fehrler, Sebastian and Michael Kosfeld (2012), Pro-Social Missions and Worker Motivation: An Experimental Study, IZA Discussion Paper No. 6460 .

[19] Ferrer-i-Carbonell, Ada and Paul Frijters (2004), How Important is Methodology for the Estimates of the Determinants of Happiness?, Economic Journal, 114(497): 641-659.

[20] Freeman, Richard (1978), Job Satisfaction as an Economic Variable, American Economic Review, 68(2): 135-141.

[21] Frey, Bruno S. and Alois Stutzer (2002), Happiness and Economics. New Jersey: Princeton University Press.

[22] Geishecker, Ingo and Maximilian Riedl (2012), Ordered Response Models and Non-Random Personality Traits: Monte Carlo Simulations and a Practical Guide, CEGE Discussion Paper No. 116. 
[23] Gerhards, Leonie (2013), Incentives for Motivated Agents: An Experiment with Employees from a Non-profit Organization, Mimeo, Goethe University Frankfurt.

[24] Ghinetti, Paolo (2007), The Public-Private Job Satisfaction Differential in Italy, Labour, 21(2): 361-388.

[25] Hamermesh, Daniel S. (1977), Economic Aspects of Job Satisfaction. In O. Ashenfelter and W. Oates (Eds.), Essays in Labor Market Analysis, pp. 53-72. New York: John Wiley.

[26] Heywood, John S., Stanley W. Siebert, and Xiangdong Wei (2001), Worker Sorting and Job Satisfaction: The Case of Union and Government Jobs, Industrial \& Labor Relations Review, 55(4): 595-609.

[27] Jensen, Jason L., Paul E. Sum, and David T. Flynn (2009), Political Orientations and Behavior of Public Employees: A Cross-National Comparison, Journal of Public Administration Research and Theory, 19(4): 709-730

[28] Knutsen, Oddbjorn (2001), Social Class, Sector Employment and Gender as Party Cleavages in the Scandinavian Countries: A Comparative Longitudinal Study, 1970-95, Scandinavian Political Studies, 24(4): 311350.

[29] Knutsen, Oddbjorn (2005), The Impact of Sector of Employment on Party Choice: A Comparative Study of 8 West European Countries, European Journal of Political Research, 44(4): 593-621.

[30] Kristof, Amy L. (1996), Person-Organization Fit: An Integrative Review of its Conceptualizations, Measurement, and Implications, Personnel Psychology, 49(1): 1-49.

[31] Leisink, Peter and Bram Steijn (2009), Public Service Motivation and Job Performance of Public Sector Employees in the Netherlands, International Review of Administrative Sciences, 75(1): 35-52.

[32] Lewis, Gregory B. and Sue A. Frank (2002), Who Wants to Work for the Government?, Public Administration Review, 62(4): 395-404. 
[33] Luechinger, Simon, Stephan Meier, and Alois Stutzer (2008), Bureaucratic Rents and Life Satisfaction, Journal of Law, Economics, and Organization, 24(2): 476-488.

[34] Luechinger, Simon, Alois Stutzer, and Rainer Winkelmann (2006), The Happiness Gains from Sorting and Matching in the Labor Market, IZA Discussion Paper No. 2019

[35] Luechinger, Simon, Alois Stutzer, and Rainer Winkelmann (2010), Selfselection Models for Public and Private Sector Job Satisfaction, Research in Labor Economics, 30: 233-251.

[36] Mangione, Thomas W. and Robert P. Quinn (1975), Job Satisfaction, Counterproductive Behavior, and Drug Use at Work, Journal of Applied Psychology, 60(1): 114-116.

[37] Rattso, Jorn and Rune J. Sorensen (2013), The Political Preferences of Public Employees: Challenging the Selection Hypothesis, Mimeo, Norwegian Business School.

[38] Shields, Michael A. and Melanie Ward (2001), Improving Nurse Retention in the National Health Service in England: the Impact of Job Satisfaction on Intentions to Quit, Journal of Health Economics, 20: 677-701.

[39] Steijn, Bram (2008), Person-Environment Fit and Public Service Motivation, International Public Management Journal, 11(1): 13-27.

[40] Taylor, Jeannette (2008), Organizational Influences, Public Service Motivation and Work Outcomes: An Australian Study, International Public Management Journal, 11(1): 67-88.

[41] Tonin, Mirco and Michael Vlassopoulos (2010), Disentangling the Sources of Pro-socially Motivated Effort: A Field Experiment, Journal of Public Economics, 94(11): 1086-1092.

[42] Tonin, Mirco and Michael Vlassopoulos (2012), Social Incentives Matter: Evidence from an Online Real Effort Experiment, IZA Discussion Paper No. 6716. 
[43] Van Praag, Bernard M. S., Paul Frijters, and Ada Ferrer-i-Carbonell (2003), The Anatomy of Subjective Well-being, Journal of Economic Behavior and Organization, 51(1): 29-49.

[44] Winkelmann, Liliana and Rainer Winkelmann (1998), Why are the Unemployed so Unhappy? Evidence from Panel Data, Economica, 65(257): $1-15$.

[45] Wooldridge, Jeffrey M. (2002), Econometric Analysis of Cross Section and Panel Data. Cambridge, MA: MIT Press.

[46] Wright, Bradley E. and Sanjay K. Pandey (2008), Public Service Motivation and the Assumption of Person-Organization Fit: Testing the Mediating Effect of Value Congruence, Administration $\&$ Society, 40(5): 502-521. 


\section{Tables}

Table 1: Description of variables used in regression

\begin{tabular}{|c|c|c|c|}
\hline Variable & Description & Mean & Std.Dev \\
\hline Job satisfaction & Self-reported job satisfaction on a $0-10$ scale. & 7.71 & 1.46 \\
\hline Government & $\begin{array}{l}\text { Variable indicating } 1 \text { if a worker is employed } \\
\text { in the government sector. }\end{array}$ & 0.13 & 0.34 \\
\hline Match & $\begin{array}{l}\text { Variable indicating } 1 \text { if a worker matches on } \\
\text { political preferences to the political parties in } \\
\text { office. }\end{array}$ & 0.46 & 0.50 \\
\hline Age & Age in years. & 44.93 & 10.82 \\
\hline Education level & $\begin{array}{l}\text { Highest attained level of education (Statistics } \\
\text { Netherlands categories): } 1=\text { primary school, } \\
2=\text { intermediate secondary, } 3=\text { higher sec- } \\
\text { ondary, } 4=\text { intermediate vocational, } 5=\text { higher } \\
\text { vocational, and } 6=\text { university. }\end{array}$ & 4.08 & 1.34 \\
\hline Subjective health & $\begin{array}{l}\text { Self reported health: } 1=\text { poor, } 2=\text { moderate, } \\
3=\text { good, } 4=\text { very good, and } 5=\text { excellent. }\end{array}$ & 3.27 & 0.70 \\
\hline Hours & Contracted weekly work hours. & 31.77 & 9.48 \\
\hline Income & Gross monthly income in euro's. & 2819 & 1651 \\
\hline Overtime & $\begin{array}{l}\text { Required to work overtime measured by: } \\
1=\text { never, } 2=\text { sometimes, and } 3=\text { often. }\end{array}$ & 1.94 & 0.60 \\
\hline Irregular hours & $\begin{array}{l}\text { Required to work irregular hours measured by: } \\
1=\text { never, } 2=\text { sometimes, and } 3=\text { often. }\end{array}$ & 1.67 & 0.76 \\
\hline Supervisor & $\begin{array}{l}\text { Variable indicating } 1 \text { if a worker has supervis- } \\
\text { ing tasks. }\end{array}$ & 0.32 & 0.47 \\
\hline Commuting time & Travel time in minutes. & 27.96 & 21.95 \\
\hline $\begin{array}{l}\text { Tenure } \\
\text { Job classification }\end{array}$ & $\begin{array}{l}\text { Years employed by current organization. } \\
\text { Worker classifications include: } 1=\text { agrarian, } \\
2=\text { blue collar, and } 3=\text { white collar. }\end{array}$ & 12.55 & 10.82 \\
\hline
\end{tabular}


Table 2: Distribution of reported votes over political parties

\begin{tabular}{lccc}
\hline Political party & $\begin{array}{r}\text { Non-government } \\
\text { employment }\end{array}$ & $\begin{array}{r}\text { Government } \\
\text { employment }\end{array}$ & Difference \\
\hline Christian Democrats (CDA) & 0.20 & 0.17 & $-0.03^{*}$ \\
Labor party (PvdA) & 0.19 & 0.25 & $0.06^{* * *}$ \\
Liberal party (VVD) & 0.18 & 0.18 & 0.00 \\
Socialist party (SP) & 0.16 & 0.11 & $-0.05^{* * *}$ \\
Green party (GroenLinks) & 0.08 & 0.06 & $-0.02^{* *}$ \\
Freedom party (PVV) & 0.06 & 0.06 & 0.00 \\
Social-Liberal party (D66) & 0.05 & 0.06 & 0.01 \\
Christian Union party (CU) & 0.04 & 0.07 & $0.03^{* * *}$ \\
Animal Welfare party (PvdD) & 0.02 & 0.01 & 0.01 \\
Christian Reformed party (SGP) & 0.01 & 0.01 & 0.00 \\
Other & 0.01 & 0.01 & 0.00 \\
\end{tabular}

Notes: A worker's reported vote is measured by the question: "For which party did you vote in the parliamentary elections of [date of election]?" *, **, and *** indicate a significant difference at the $.10, .05$, and .01 levels, respectively. 
Table 3: Results of the fixed effects estimation on job satisfaction

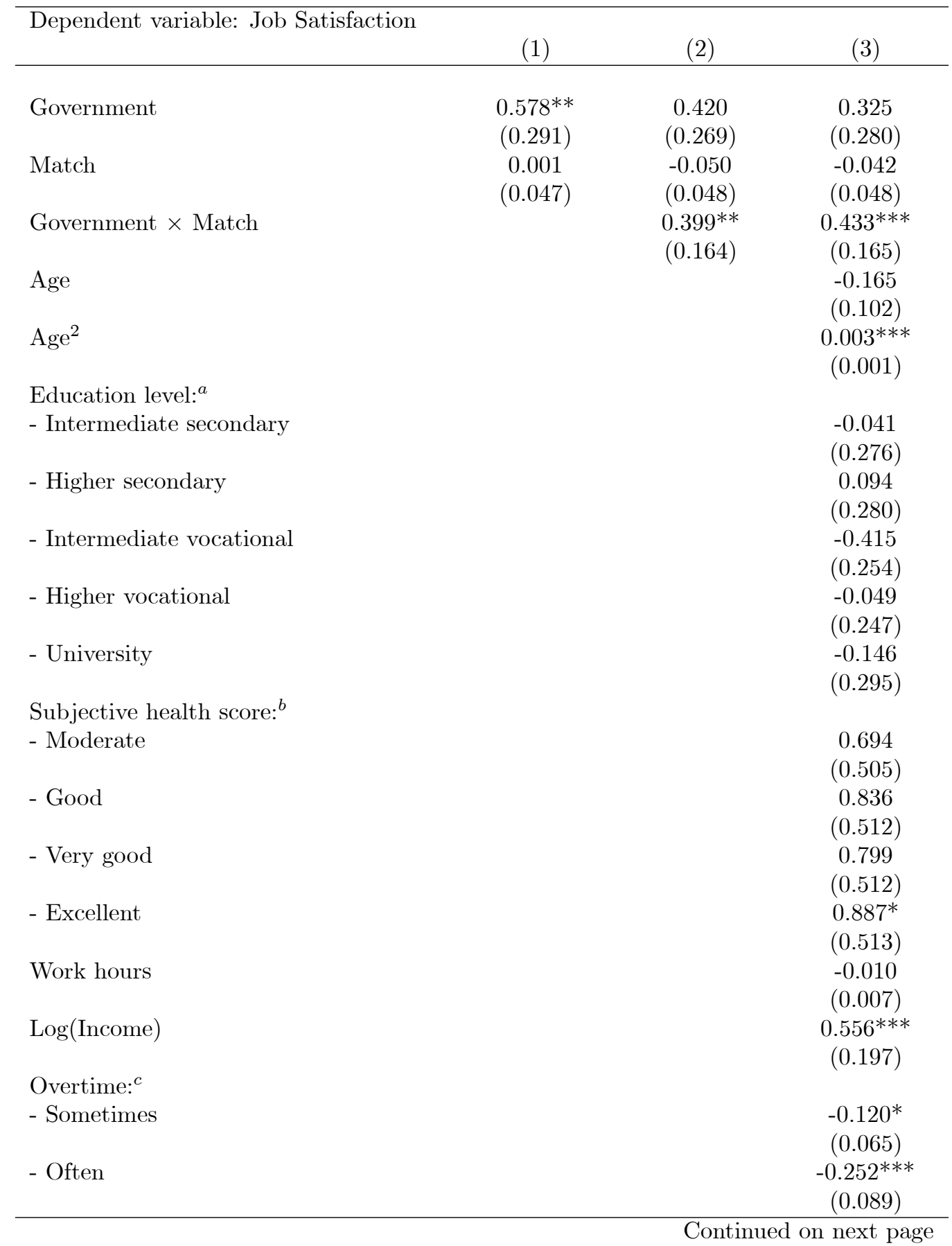


Table 3 - continued from previous page

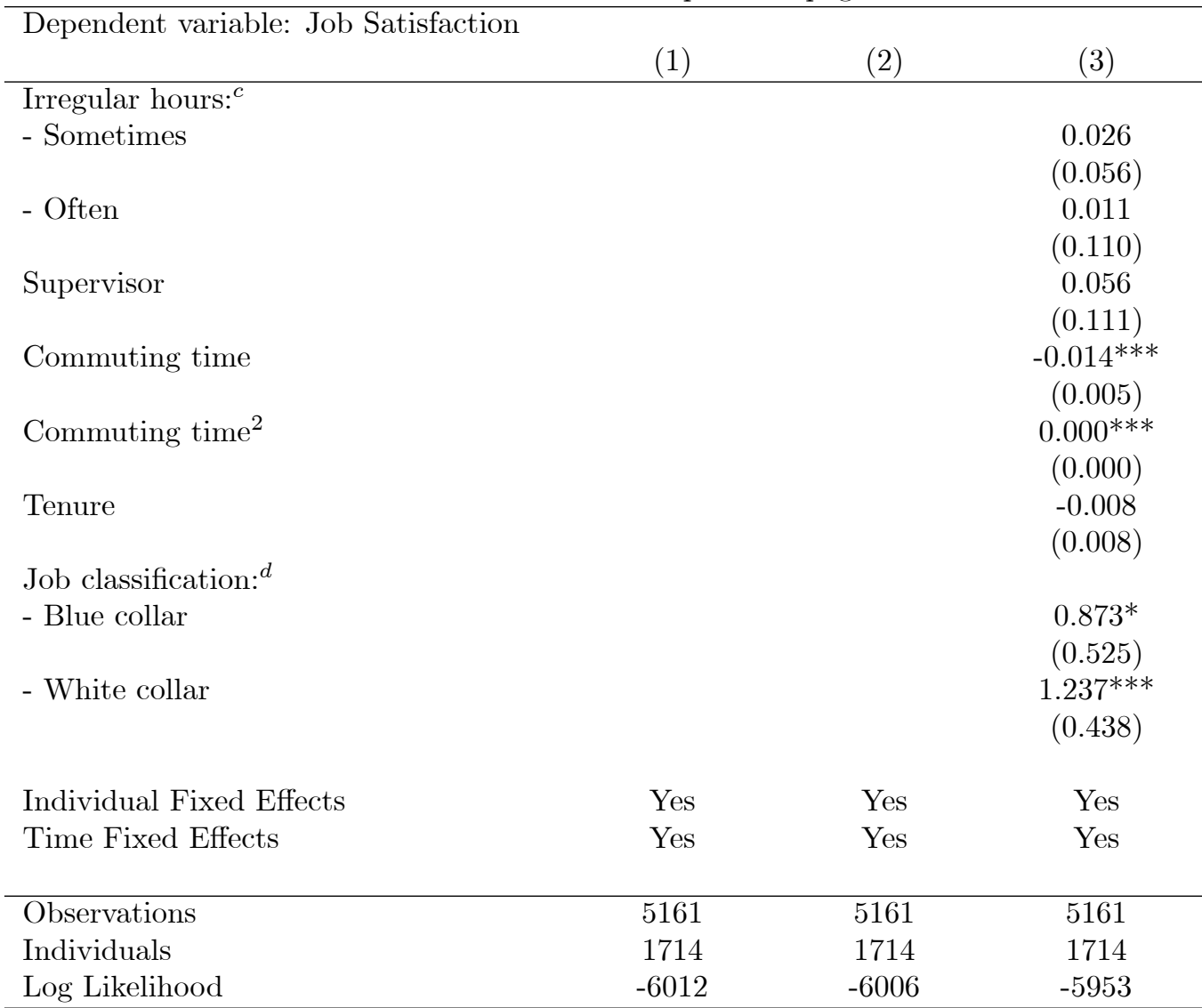

Notes: Standard errors between parentheses are clustered at the individual level. ${ }^{a}$ Reference category: "Primary education". ${ }^{b}$ Reference category: "Poor health". ${ }^{c}$ Reference category: "Never". ${ }^{d}$ Reference category: "Agrarian". *, **, and *** indicate significance based on a two sided test at the .10, .05, and .01 levels, respectively. 
Table 4: Marginal effects by education level

\begin{tabular}{lccc}
\hline & $\begin{array}{c}(1) \\
\text { Low } \\
\text { Educated }\end{array}$ & $\begin{array}{c}(2) \\
\text { Intermediate } \\
\text { Educated }\end{array}$ & $\begin{array}{c}(3) \\
\text { High } \\
\text { Educated }\end{array}$ \\
\hline Marginal effect of match: & & & \\
$\quad$ Non-government employment & -0.097 & -0.094 & 0.013 \\
& $(0.120)$ & $(0.085)$ & $(0.065)$ \\
Government employment & 0.360 & $0.697^{* *}$ & 0.228 \\
& $(0.322)$ & $(0.291)$ & $(0.223)$ \\
Marginal effect of government employment: & & & \\
Non-matching preferences & 0.316 & -0.044 & 0.488 \\
& $(0.362)$ & $(0.376)$ & $(0.340)$ \\
Matching preferences & $0.773^{* *}$ & $0.748^{*}$ & $0.703^{*}$ \\
& $(0.394)$ & $(0.395)$ & $(0.412)$ \\
& & & \\
\hline
\end{tabular}

Notes: Marginal effects calculated based on equation (1) with additional two-way and three-way interactions between the variables match, government and education. The variable education is recoded into (1) low education: primary school or intermediate secondary, (2) intermediate education: higher secondary or intermediate vocational, and (3) high education: higher vocational or university. Delta method standard errors between parentheses. ${ }^{*}, * *$, and ${ }^{* * *}$ indicate significance based on a two sided test at the $.10, .05$, and .01 levels, respectively. 
Table 5: Average reported stance towards individual political parties

\begin{tabular}{|c|c|c|c|}
\hline Political party & $\begin{array}{c}\text { Non-government } \\
\text { employment }\end{array}$ & $\begin{array}{l}\text { Government } \\
\text { employment }\end{array}$ & Difference \\
\hline Christian Democrats (CDA) & $\begin{array}{c}5.20 \\
(0.032)\end{array}$ & $\begin{array}{c}5.28 \\
(0.078)\end{array}$ & 0.07 \\
\hline Labor party (PvdA) & $\begin{array}{c}5.33 \\
(0.031)\end{array}$ & $\begin{array}{c}5.45 \\
(0.082)\end{array}$ & 0.12 \\
\hline Liberal party (VVD) & $\begin{array}{c}5.16 \\
(0.032)\end{array}$ & $\begin{array}{c}5.10 \\
(0.080)\end{array}$ & -0.06 \\
\hline Socialist party (SP) & $\begin{array}{c}5.36 \\
(0.033)\end{array}$ & $\begin{array}{c}5.06 \\
(0.082)\end{array}$ & $-0.30 * * *$ \\
\hline Green party (GroenLinks) & $\begin{array}{c}5.30 \\
(0.035)\end{array}$ & $\begin{array}{c}5.34 \\
(0.086)\end{array}$ & 0.04 \\
\hline Freedom party (PVV) & $\begin{array}{c}2.88 \\
(0.044)\end{array}$ & $\begin{array}{c}2.51 \\
(0.109)\end{array}$ & $-0.36^{* * *}$ \\
\hline Social-Liberal party (D66) & $\begin{array}{c}5.44 \\
(0.032)\end{array}$ & $\begin{array}{c}5.59 \\
(0.081)\end{array}$ & $0.15^{*}$ \\
\hline Christian Union party (CU) & $\begin{array}{c}4.48 \\
(0.035)\end{array}$ & $\begin{array}{c}4.53 \\
(0.089)\end{array}$ & 0.05 \\
\hline Animal Welfare party (PvdD) & $\begin{array}{c}3.72 \\
(0.039)\end{array}$ & $\begin{array}{c}3.68 \\
(0.098)\end{array}$ & -0.04 \\
\hline Christian Reformed party (SGP) & $\begin{array}{c}3.33 \\
(0.035)\end{array}$ & $\begin{array}{c}3.27 \\
(0.085)\end{array}$ & -0.06 \\
\hline
\end{tabular}

Notes: A worker's opinion is measured on a ten-point scale by the question: "What do you think of [party name]?" Standard errors between parentheses. *, **, and *** indicate a significant difference in means at the $.10, .05$, and .01 levels, respectively. 


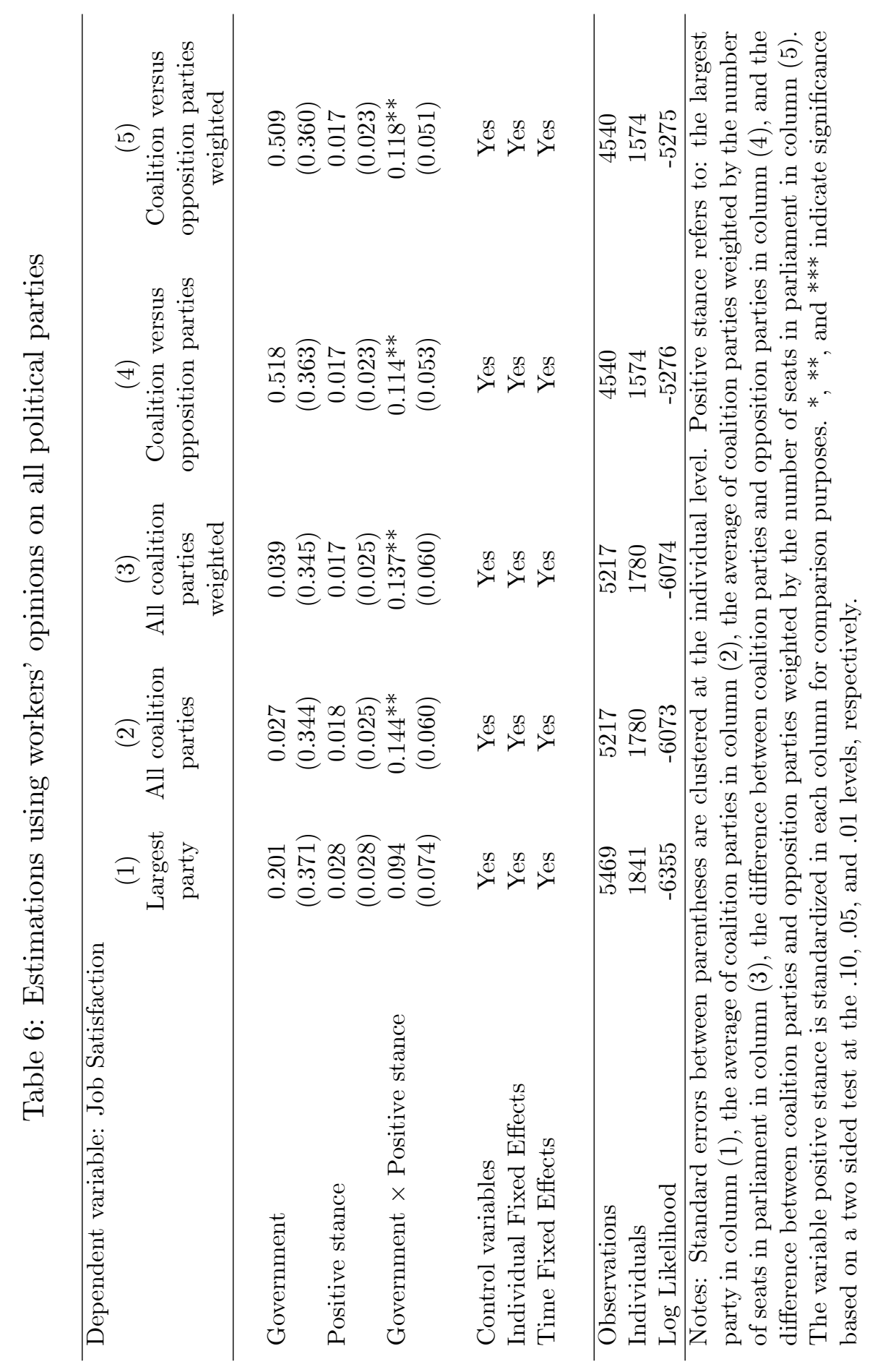




\section{Figures}

Figure 1: Average job satisfaction over the observation period by sector

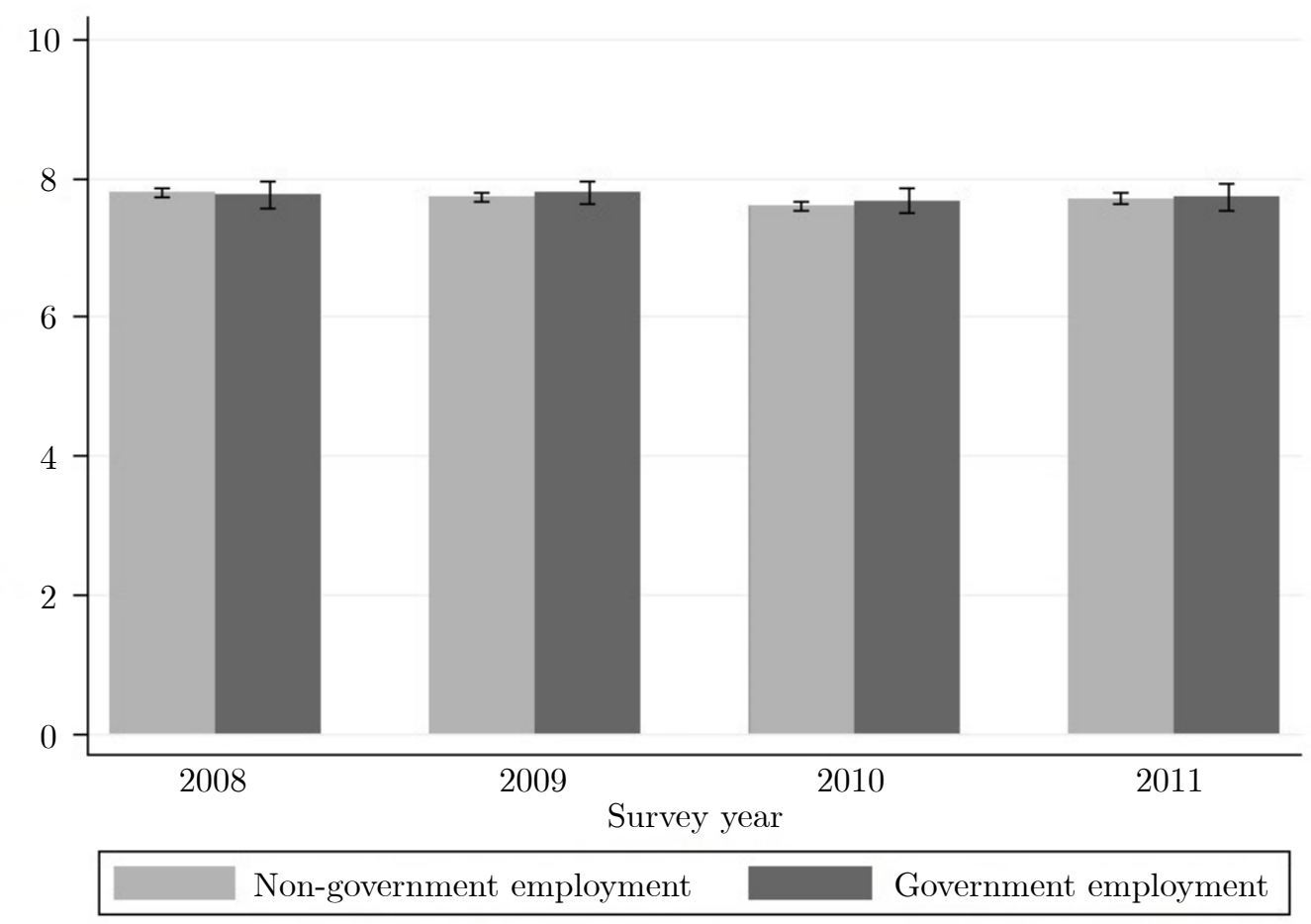

Notes: Histogram shows the average reported job satisfaction in each year including a 90\% confidence interval. 
Figure 2: Average job satisfaction of government workers over the observation period

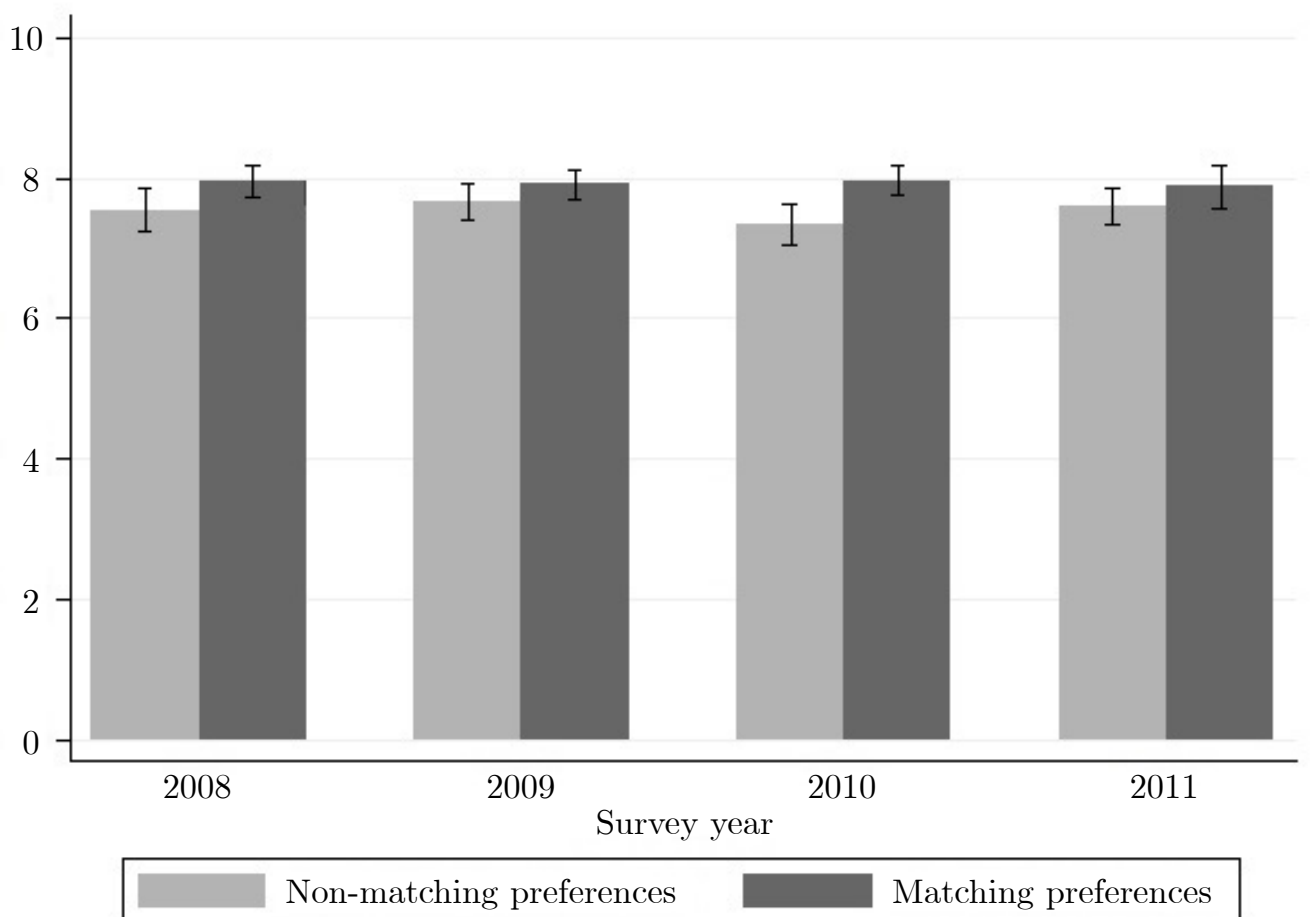

Notes: Histogram shows the average reported job satisfaction in each year including a $90 \%$ confidence interval. 


\section{A Appendix}

Table A.1: Results of the ordered logit fixed effects estimation on job satisfaction

\begin{tabular}{|c|c|c|c|}
\hline Dependent variable: Job Satisfaction & $(1)$ & $(2)$ & $(3)$ \\
\hline Government & $\begin{array}{c}1.195^{* *} \\
(0.536)\end{array}$ & $\begin{array}{c}0.772 \\
(0.508)\end{array}$ & $\begin{array}{c}0.793 \\
(0.536)\end{array}$ \\
\hline Match & $\begin{array}{c}0.011 \\
(0.114)\end{array}$ & $\begin{array}{c}-0.102 \\
(0.119)\end{array}$ & $\begin{array}{c}-0.073 \\
(0.118)\end{array}$ \\
\hline Government $\times$ Match & & $\begin{array}{c}0.820^{* *} \\
(0.349)\end{array}$ & $\begin{array}{c}0.810^{* *} \\
(0.357)\end{array}$ \\
\hline $\begin{array}{l}\text { Control variables } \\
\text { Individual Fixed Effects } \\
\text { Time Fixed Effects }\end{array}$ & $\begin{array}{l}\text { No } \\
\text { Yes } \\
\text { Yes }\end{array}$ & $\begin{array}{l}\text { No } \\
\text { Yes } \\
\text { Yes }\end{array}$ & $\begin{array}{l}\text { Yes } \\
\text { Yes } \\
\text { Yes }\end{array}$ \\
\hline Log Likelihood & -2523 & -2517 & -2455 \\
\hline
\end{tabular}

